\title{
Recovery from bark harvesting of 12 medicinal tree species in Benin, West Africa
}

\author{
Claire Delvaux ${ }^{1 *}$, Brice Sinsin ${ }^{2}$, François Darchambeau ${ }^{3}$ and Patrick Van Damme ${ }^{1}$ \\ ${ }^{1}$ Laboratory of Tropical and Subtropical Agronomy and Ethnobotany, Department of Plant Production, University of Ghent, \\ Ghent, Belgium; 'Laboratoire d'Ecologie Appliquée, Faculté des Sciences Agronomiques, Université d'Abomey-Calavi, \\ Cotonou, Bénin; and ${ }^{3}$ Unit of Research on Biology of Organisms, Department of Biology, University of Namur, Namur, \\ Belgium
}

\section{Summary}

1. The growing interest in medicinal plants from both international industry and local markets requires management of tree bark harvesting from natural forests in order to prevent inappropriate exploitation of target species. This study was designed to determine the bark re-growth response of a selected number of medicinal tree species as a basis for the development of an optimal bark harvesting method.

2. In 2004, bark was harvested from 925 trees belonging to 12 species in 38 sites in a dry forest in Benin, West Africa. Two years later, the response of trees to bark harvesting was examined with respect to re-growth (edge or sheet), development of vegetative growth around the wound, and the sensitivity of the wound to insect attack.

3. Two species, Khaya senegalensis and Lannea kerstingii, showed complete wound recovery by edge growth. At the other extreme, Afzelia africana, Burkea africana and Maranthes polyandra had very poor edge growth. $M$. polyandra showed good sheet growth, whereas the other 11 species had none or poor sheet growth after total bark harvesting. In contrast, partial bark removal allowed better sheet growth in all 12 species studied.

4. Insect sensitivity was species-specific. Insect attacks were negatively correlated with nonrecovered wound area, but there was a marked species effect for the same rate of regeneration. $L$. kerstingii and $K$. senegalensis had very good and similar re-growth, but $L$. kerstingii was very susceptible to insect attack, whereas $K$. senegalensis appeared to be very resistant. Only a few individuals developed vegetative growth, and each tree usually developed only one or two agony shoots, but there was no significant difference between species.

5. Synthesis and applications. This is the first study to provide data on the ability of trees to close wounds after bark harvesting in West Africa. We report large variability in the response of different species to our bark harvesting technique, and identify just two out of the 12 study species as suitable for sustainable bark harvesting. Based on our results, we developed a decisional step method to help forest managers select the best techniques for managing medicinal tree species as an alternative to bark harvesting, for example, coppice management, harvesting leaves instead of bark, stand establishment, and collaboration with timber companies.

Key-words: bark, medicinal trees, re-growth, West Africa, insect attack, vegetative growth, wound, sustainable harvesting, forest management

\section{Introduction}

Two of the many threats to medicinal plant species are the loss of local knowledge about their use and the loss of species from the wild due to over-harvesting. The sum of human know-

*Correspondence author. E-mail: claire.delvaux@ugent.be ledge about the types, distribution, ecology and management of medicinal plants, and methods for extracting the active components shows rapid decline (Hamilton 2004). This loss of local knowledge has been ongoing for hundreds of years. In recent decades, many ethnobotanical and ethnopharmaceutical studies have been undertaken to document and describe traditional herbal products and to validate their use (Light 
et al. 2005). During that period, however, many plants have become threatened due to a lack of local control on harvesting levels. The global demand for herbal medicine is large, and steadily growing (Srivastava 2000; Light et al. 2005), which has caused some valued indigenous plant species to become threatened or, in some cases, to go extinct (Williams, Balkwill \& Witkowski 2000; Shingu 2005). Medicinal plants can have other uses (e.g. timber, firewood, fodder, etc.), and the threat of over-harvesting may be due, at least partly, to gathering for other purposes (Hamilton 2004).

There is an urgent need to develop appropriate conservation strategies to promote sustainable use of medicinal plant through improved harvesting techniques, cultivation and monitoring (Cunningham 1991; Schippmann, Leaman \& Cunningham 2002; Botha, Witkowski \& Shackleton 2004; Light et al. 2005; Belcher, Ruiz-Pérez \& Achdiawan 2005; Geldenhuys 2007).

The sustainable management of medicinal tree species is far from simple. First, the exploitation of these species has a variable effect on the plants themselves, depending on the parts harvested. For example, harvesting flowers and fruits has a significant impact on regeneration and on the population viability (Hall \& Bawa 1993; Peters 1994; Witkowski \& Lamont 1994; Endress, Gorchov \& Noble 2004; Gaoue $\&$ Ticktin 2008). However, harvesting bark or roots is more damaging in terms of tree survival (Cunningham 1991; Peters 1994; Witkowski \& Lamont 1994; Davenport \& Ndangalasi 2002; Geldenhuys 2004; Vermeulen 2006). Secondly, most medicinal plants are harvested for more than one reason (Shackleton et al. 2002). As suggested for non-timber forest products (Ticktin 2005), the sustainable management of medicinal trees requires knowledge of how different species respond to different harvesting techniques. In general, the production rate of the resource will determine how much of it can be used sustainably (Geldenhuys 2004).

This study examined the impact of bark harvesting on trees in order to promote sustainable management of medicinal trees. The term bark is generally considered to include all tissues outside the vascular cambium, regardless of their composition (Junikka 1994). The complexity of the bark tissues derives from the presence of a mixture of dead and live tissues. The rhytidome is the dead outer part of the bark that serves as a physical barrier and protects the tree against attack by herbivores, insects, fire, and fungi. The live tissue called phloem constitutes the inner bark, which is also called noncollapsed secondary phloem because it is the part of the secondary phloem that contains open and non-collapsed sieve elements (Trockenbrodt 1990). Elaborated sap is transported from leaves to roots through these non-collapsed sieve elements. A simple wound in the bark can easily disrupt the physiological functioning of a tree; continuous development of new vascular tissues (Aloni 1987) allows the regeneration of the wounded part of the tree.

Bark from numerous species has long been used by humans for the treatment of diseases, such as fungal skin infections (Milicia excelsa), fever (Alstonia constricta), malaria (Cinchona officinalis) and benign prostatic hyperplasia (Prunus africana).
Sustainable bark harvesting techniques vary among species, depending on the ability of individual trees to survive harvesting and recover from the inflicted wound. Throughout Africa, only a few studies have assessed the ability of trees to regenerate bark following harvesting. In Cameroon, Cunningham \& Mbenkum (1993) showed that P. africana achieves complete bark re-growth of the bark after ringbarking. Similar studies in Nigeria (Fasola \& Egunyomi 2005) indicate that Alstonia boonei, Entandophragma angolense, Khaya grandifolia, Khaya senegalensis and Spondias mombin belong to the fast re-growth group, whereas the bark of Adansonia digitata, Gliricidia sepium, Newbouldia laevis and Theobroma cacao have relatively slow re-growth. In South Africa, P. africana, Ocotea bullata and Warburgia salutaris show good re-growth; in contrast, the bark of Rapanea melanophloeos shows no re-growth (Geldenhuys et al. 2007; Vermeulen 2006). These results show clearly that the ability to regenerate bark after harvesting is species-specific.

In Benin, a nationwide ethnobotanical survey (Adjanohoun et al. 1989) showed that bark represents $10 \cdot 5 \%$ of medicinal plant products, and that $31.5 \%$ of tree species occurring in the country are used for their bark. The present study was done in Benin and assessed the impact of bark harvesting on 12 tree species used by local communities living around the Forêt Classée des Monts Kouffé, central Benin. We hypothesized that these 12 medicinal tree species (Table 1) might differ in their ability to recover from wounding. More specifically, the objectives of the study were: (i) to compare the regenerative ability (edge and sheet re-growth) for the 12 species; (ii) to assess the impact of bark harvesting on vegetative growth (shoot development around the wound) and insect attack; and (iii) to develop a species-specific method for sustainable management of bark harvesting.

\section{Materials and methods}

\section{STUDY AREA}

The study was conducted in the Forêt Classée des Monts Kouffé $\left(8^{\circ} 30^{\prime}-8^{\circ} 52^{\prime} \mathrm{N}, 1^{\circ} 40^{\prime}-2^{\circ} 27^{\prime} \mathrm{E}\right)$ in central Benin, West Africa (Fig. 1). This area covers 180300 ha within the Sudano-Guinean phytogeographic region. The average monthly temperature is $21-33.2{ }^{\circ} \mathrm{C}$ and the average annual precipitation is $1190.7 \mathrm{~mm}$. The study was carried out in woodland.

\section{STUDY SPECIES}

As a first step, a large number of medicinal tree species were selected in order to be able to compare a sufficient diversity of response to bark harvesting. Interviews were held with traditional healers and local populations in order to learn their preference for tree species used for health care (Bockx 2004), and 12 of the most frequently used species of trees were chosen for the study (Table 1).

\section{SAMPLING DESIGN AND HARVESTING TREATMENT}

Sites with sufficient numbers of the chosen species were selected, and all were situated within the forest and away from agricultural 
Table 1. The 12 tree species in this study. The number of individual trees $(\mathrm{N})$ and the range of diameter at breast height (d.b.h.) values are given

\begin{tabular}{|c|c|c|c|c|c|}
\hline Species & Familly & $\begin{array}{l}\text { Height } \\
\text { (standard) (m) }\end{array}$ & d.b.h. (standard) (cm) & $\mathrm{N}$ & $\begin{array}{l}\text { d.b.h. } \\
\text { (studied) (cm) }\end{array}$ \\
\hline Afzelia africana $\mathrm{Sm}$. & Caesalpinaceae & $25-30$ & $40-60(>100)$ & 68 & $15 \cdot 6-41 \cdot 7$ \\
\hline Burkea africana Hook. & Caesalpinaceae & $10-12(20)$ & $40-60(>80)$ & 78 & $11 \cdot 6-44 \cdot 0$ \\
\hline Detarium microcarpum Guill. \& Perr. & Caesalpinaceae & $8-10$ & $20-30(50)$ & 82 & $13 \cdot 5-45$ \\
\hline Khaya senegalensis (Desv.) A. Juss. & Meliaceae & $25-35$ & $40-70(130)$ & 73 & $12-36 \cdot 4$ \\
\hline Lannea kerstingii Engl. \& K. Krause & Anacardiaceae & 12 & $40-60(70)$ & 48 & $17-44 \cdot 9$ \\
\hline Lophira lanceolata Van Tiegh. ex Keay & Ochnaceae & $8-10$ & $20-30(40)$ & 102 & $14 \cdot 9-36 \cdot 4$ \\
\hline Mangifera indica $\mathrm{L}$. & Anacardiaceae & $10-15(30)$ & $20-30(60)$ & 86 & $12 \cdot 2-47 \cdot 2$ \\
\hline Maranthes polyandra (Benth.) Prance & Chrysobalanaceae & $6-8$ & $15-25(40)$ & 53 & $12 \cdot 8-35 \cdot 1$ \\
\hline Parkia biglobosa (Jacq.) R. Br. ex G. Don & Mimosaceae & $10-15$ & $30-50(150)$ & 44 & $14-49 \cdot 5$ \\
\hline Pterocarpus erinaceus Poir. & Papillonaceae & $8-12$ & $30-50(100)$ & 96 & $13 \cdot 5-40 \cdot 5$ \\
\hline Pseudocedrela kotschyi (Schweinf.) Harms & Meliaceae & $9-12$ & $20-30(40)$ & 93 & $13 \cdot 3-40 \cdot 4$ \\
\hline Uapaca togoensis $\mathrm{Pax}$ & Euphorbiaceae & $10-15$ & $20-30(50)$ & 102 & $12 \cdot 3-48 \cdot 2$ \\
\hline
\end{tabular}

Table 2. Description of repartition into four score levels of four variables describing resistance and response of trees after bark harvesting: edge growth and sheet growth (percentage of recovered area), resistance to insect attack (number of holes/tree) and production of agony shoots (percentage trees with agony shoots)

\begin{tabular}{lllll}
\hline Levels & Edge growth (\%) & Sheet growth (\%) & Resistance to insect (N) & Agony shoot (\%) \\
\hline $4=$ very good & $>50$ & $>50$ & 0 & $>50$ \\
$3=$ medium & $11-50$ & $11-50$ & $1-20$ & $21-50$ \\
$2=$ poor & $1-10$ & $1-10$ & $21-50$ & $1-20$ \\
$1=$ null & 0 & 0 & $>50$ & 0 \\
\hline
\end{tabular}

activity. Only healthy trees (no previous bark harvest) were selected. Bark was harvested from a total of 925 trees from 38 sites in the dry season (February and March) and in the rainy season (September and October) in 2004. The number of individual trees per species is given in Table 1. The reasons for differences in the number of trees per species were: (i) difficulty in finding trees with an appropriate diameter according to the species morphology. In the wild, it is rare to find examples of B. africana, D. microcarpum or M. polyandra with a diameter at breast height (d.b.h.) $>30 \mathrm{~cm}$. (ii) Some species (A. africana, K. senegalensis, P. kotschyi, and P. erinaceus) had been heavily harvested for timber, and thus, trees with d.b.h. higher $>30 \mathrm{~cm}$ were scarce in the study area. (iii) Some species naturally have a sparse distribution (e.g. L. kerstingii, and P. biglobosa) and finding a sufficient number of these species would have required excessive travelling and time.

Bark was collected from all species according to the same protocol. Wounds were usually made at $1-\mathrm{m}$ stem height. The wound consisted of a rectangular piece of bark $60 \mathrm{~cm}$ vertically, and the lateral extent of the wound varied between $5 \mathrm{~cm}$ and $61.8 \mathrm{~cm}$, depending on the diameter of the tree, affecting from 20 to $100 \%$ (girdling or ringbarking) of its circumference. Two treatments were used on each tree in order to compare different bark harvesting techniques and their impact on the ability of a tree species to recover from the wound. In one treatment, the bark was harvested only thinly in the upper $30 \mathrm{~cm}$ half of the wound to determine if incomplete debarking favours wound closure. Bark was peeled from the trunk in such a way that a thin layer of inner bark and the cambium were not removed. The amount of bark left on the trunk was much the same for all trees thus treated, and the surface area harvested was $20-50 \%$ of the total wound area. To guarantee uniform treatment, all samples were collected by the same three people. In the second treatment, no bark or cambium was left on the lower $30 \mathrm{~cm}$ of the wound so that the wood was completely exposed to air. This is the method used by commercial bark harvesters. For total bark removal, the wound was inflicted with a cutlass machete cutting the bark down to the cambium level and then removing it from the trunk by tapping with a hammer.

\section{MEASUREMENTS}

Two years after bark harvesting, five measurements were taken for each wound. Individual tree response was then classified according to the score levels given in Table 2 .

1. Sheet growth, that is, live tissue re-growth on the surface of the wound. (i) On the lower $30 \mathrm{~cm}$ of the bark treatment, tracing paper was used to copy the surface area of sheet growth on the wound. (ii) On the upper $30 \mathrm{~cm}$ of the wound, the sheet growth percentage was estimated visually as pieces of bark remaining prevented the use of tracing paper. The results were expressed as a percentage of re-growth area.

2. Edge growth, that is, the surface of live tissue developing from the edge of the wound. This measurement was made only on the lower $30 \mathrm{~cm}$ of the wound; three horizontal measurements were made from fixed points on both sides (left and right) of the wound to obtain the mean edge growth value. The results were expressed as a percentage of re-growth area.

3. Insect holes in the lower $30 \mathrm{~cm}$ of the wound were counted.

4. The number of agony shoots around the wound was counted. An agony shoot was defined by Geldenhuys, Rau \& Du Toit (2002) as a vegetative shoot developing around a wound in response to wounding. 


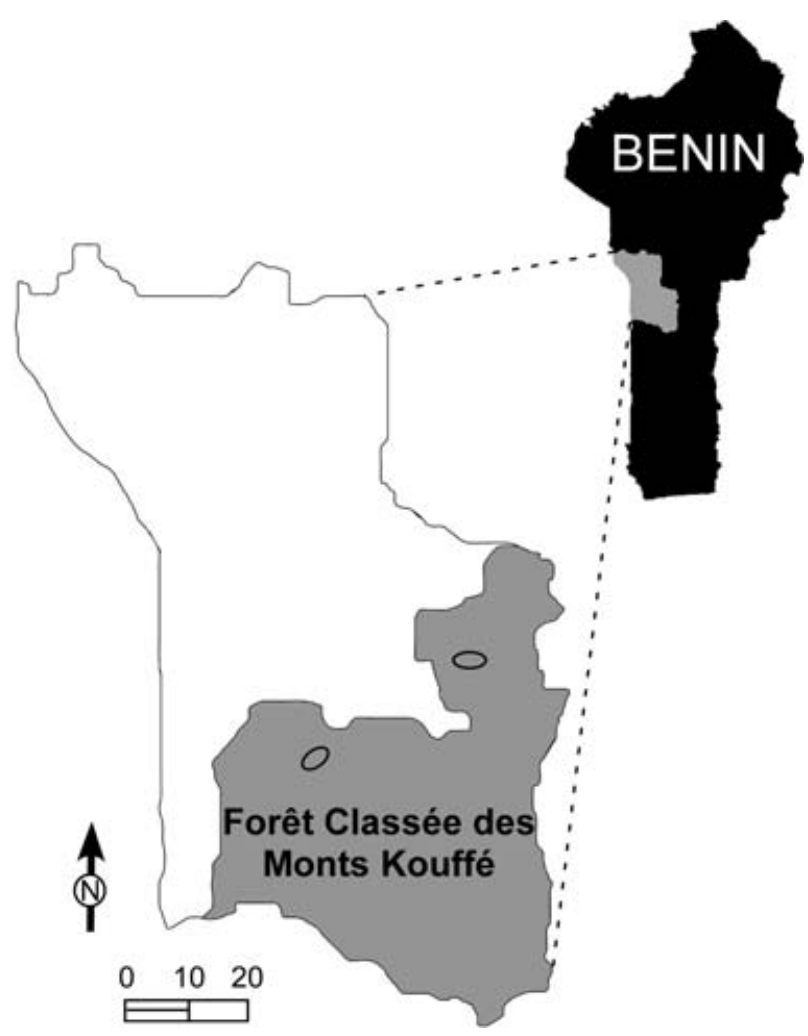

Fig. 1. A map of the study area in the Forêt Classée des Monts Kouffé in Benin. Circles represent the distribution of the two field stations where the 38 sites were chosen.

\section{DATA ANALYSES}

To compare sheet growth and edge growth between species, individual scores were calculated according to the levels given in Table 2. Ordinal score levels were compared between species by a proportional-odds logit model using the polr procedure in R environment (R Development Core Team 2005). A generalized linear model (GLM) with a quasi-Poisson error distribution was used to determine the effects of species and re-growth ability on the number of insect holes. The surface of the non-regenerated area was used as a proxy of the tree regeneration rate, and was calculated as the sum of the sheet and edge re-growth surfaces. The effects of regeneration rate and species were added sequentially for adjusting species effects for different regeneration rates. Also, a GLM with a quasi-Poisson error distribution was used to determine the effect of species on the number of agony shoots.

\section{Results}

\section{SHEET GROWTH}

Comparison of sheet growth after complete bark removal clearly showed the re-growth to be poor to non-existent for all of the 12 species (Fig. 2). M. polyandra and P. erinaceus had slightly better sheet growth compared to the other 10 species (proportional-odds logit model on score levels, $P<0.05$ ) but both species had a high intra-specific variability (Fig. 2). $M$. polyandra had the best sheet growth: $58 \cdot 2 \%$ of trees showed a re-growth process but the surface of the re-growth area varied from $1 \cdot 3$ to $98 \cdot 7 \%$. There was no sheet growth for B. africana, M. indica or P. kotschyi, and $\sim 90 \%$ of the specimens of the other seven species had no sheet growth. Complete wound closure by sheet growth was not observed after complete bark removal.

In contrast, sheet growth after partial bark harvesting was more successful in completing wound closure (Fig. 2). In $K$. senegalensis and L. kerstingii, $74 \cdot 1 \%$ and $55 \cdot 3 \%$ of trees were able to close the wound completely, whereas only $14 \cdot 8 \%$ and $31.6 \%$ of these trees, respectively, had no sheet growth. On the other hand, more than $55 \%$ of individuals of seven species showed no sheet growth. Among these species, L. lanceolata, P. biglobosa, P. kotschyi and U. togoensis had a high intraspecific variability (Fig. 2), and some trees had a sheet growth of $>75 \%$ of the wound area. Good sheet growth after partial bark harvesting was observed also in $P$. erinaceus, although few trees had achieved complete wound closure after 2 years.

There was significantly more sheet growth after partial bark removal than there was after total bark harvesting for all 12 species (proportional-odds logit model on score levels, $P<0.005$; Fig. 2). K. senegalensis, L. kerstingii, P. erinaceus, and $M$. indica had the best recovery rates, with a mean sheet growth of $83 \cdot 3 \%, 65 \cdot 5 \%, 49 \cdot 3 \%$, and $39 \cdot 2 \%$ of the wound area, respectively, after a partial harvesting vs. a mean sheet growth of $1 \cdot 9 \%, 1 \cdot 2 \%, 7 \cdot 7 \%$, and $0 \%$, respectively, after total bark harvesting. It is interesting to note that $B$. africana, $P$. kotschyi and $M$. indica, which had no sheet growth after total bark harvesting, had significant sheet growth after partial bark removal, although it was poor for $B$. africana and $P$. kotschyi ( $3 \cdot 14 \%$ and $11 \cdot 12 \%$ of total wound area, respectively).

\section{EDGE GROWTH}

Edge growth was variable among species (Fig. 3). K. senegalensis and $L$. kertingii presented a significantly opposed reaction compared with $M$. polyandra, $A$. africana and $B$. africana. Indeed, $K$. senegalensis and $L$. kerstingii had the highest mean edge recovery rate of $88.8 \%$ and $80 \cdot 4 \%$, respectively. After 2 years, only these two species closed their wounds completely through edge growth: $48 \cdot 9 \%$ of all $K$. senegalensis and $35 \cdot 3 \%$ of all L. kerstingii trees showed full recovery (Fig. 3). M. polyandra, A. africana and B. africana had the poorest edge growth, and $>60 \%$ of these species had no edge growth. P. erinaceus, $P$. kotschyi, $P$. biglobosa and $M$. indica had a mean edge recovery rate of $23 \cdot 1-40 \cdot 1 \%$ and high intra-specific variability (Fig. 3).

\section{INTENSITY OF INSECT ATTACKS}

The number of insect holes was clearly species-dependent (Fig. 4). D. microcarpum and P. biglobosa showed the least resistance to insect attack, while several other species, such as $K$. senegalensis, P. erinaceus, M. polyandra, and U. togoensis, were highly resistant. There was a significant positive effect of the surface of non-regenerated area on the frequency of insect attacks $(P<0.001)$, illustrating that fast recovery prevents 

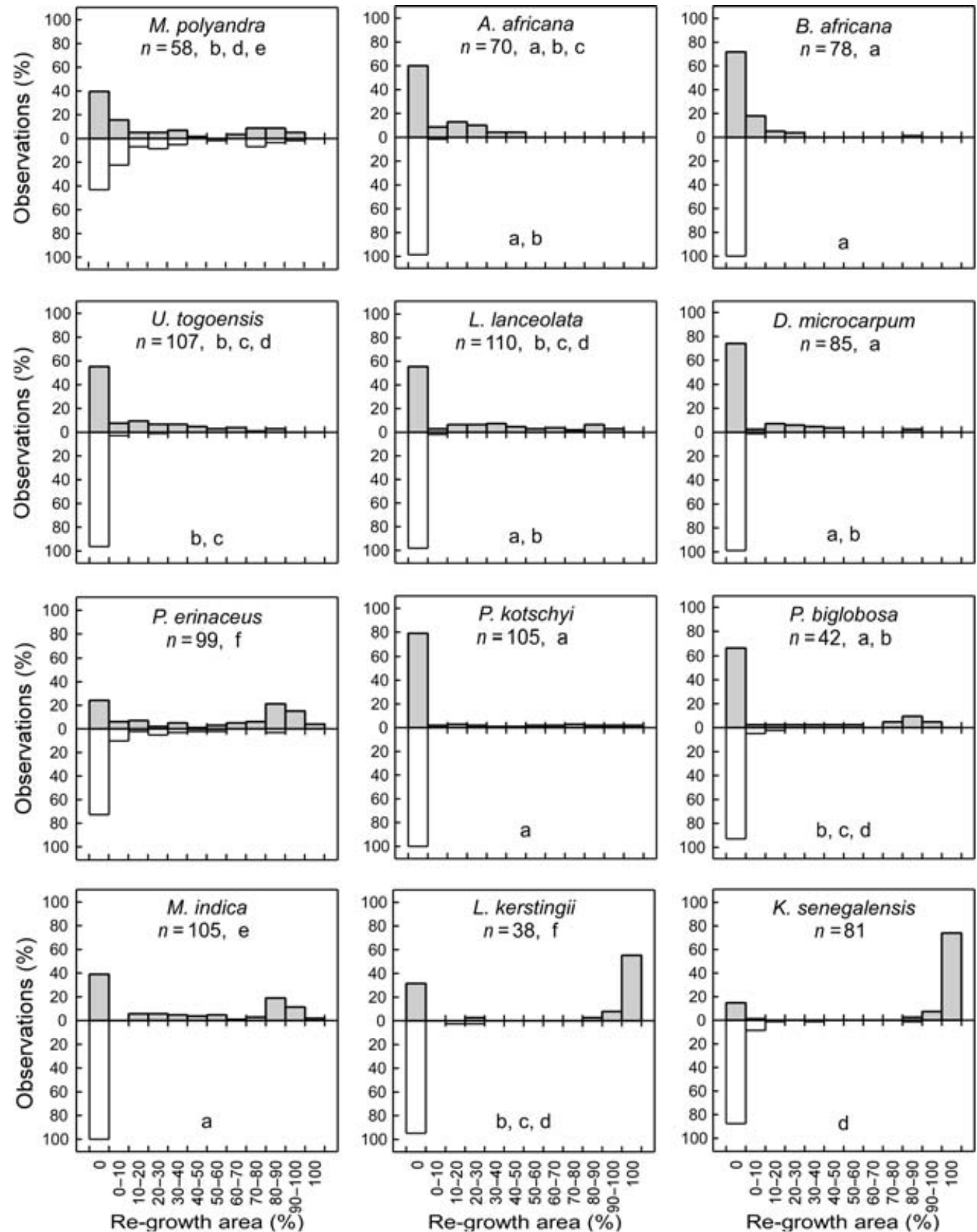

Fig. 2. Frequency histograms summarizing the sheet growth of 12 medicinal tree species during 2 years following bark harvesting. Grey boxes are for re-growth observed after partial bark harvesting, white boxes are for re-growth after total bark harvesting (both techniques were used on each tree). Identical small letters indicate species with no significant difference in sheet growth at the $P \leq 0.05$ confidence level (proportionalodds logit model on score levels, see Table 2).

large-scale insect damage. The effect of species adjusted for different regeneration rates was highly significant $(P<0 \cdot 001)$, but there was no significant interaction between regeneration rate and species $(P=0 \cdot 100)$, illustrating that the relationship between regeneration rate and the number of insect holes was not species-specific. It is interesting to note that both $K$. senegalensis and L. kerstingii had very good edge growth, reducing their wound area considerably, but their susceptibility to insect attack was quite different: $K$. senegalensis was resistant but $L$. kerstingii was highly susceptible to insect attack. The damage inflicted by insects may weaken the stability of trees, and eventually trees may crack. Over a period of 2 years, $17 \cdot 3 \%$ of all L. kerstingii and $6 \cdot 8 \%$ of all P. biglobosa were broken following insect attacks, while no D. microcarpum, B. africana or A. africana trees died from insect attack.

\section{RESPONSE TO BARK HARVESTING IN TERMS OF VEGETATIVE GROWTH}

The development of agony shoots around the wound in response to bark harvesting was largely dependent on species $(P<0 \cdot 001)$. In this study, only a few trees developed agony 

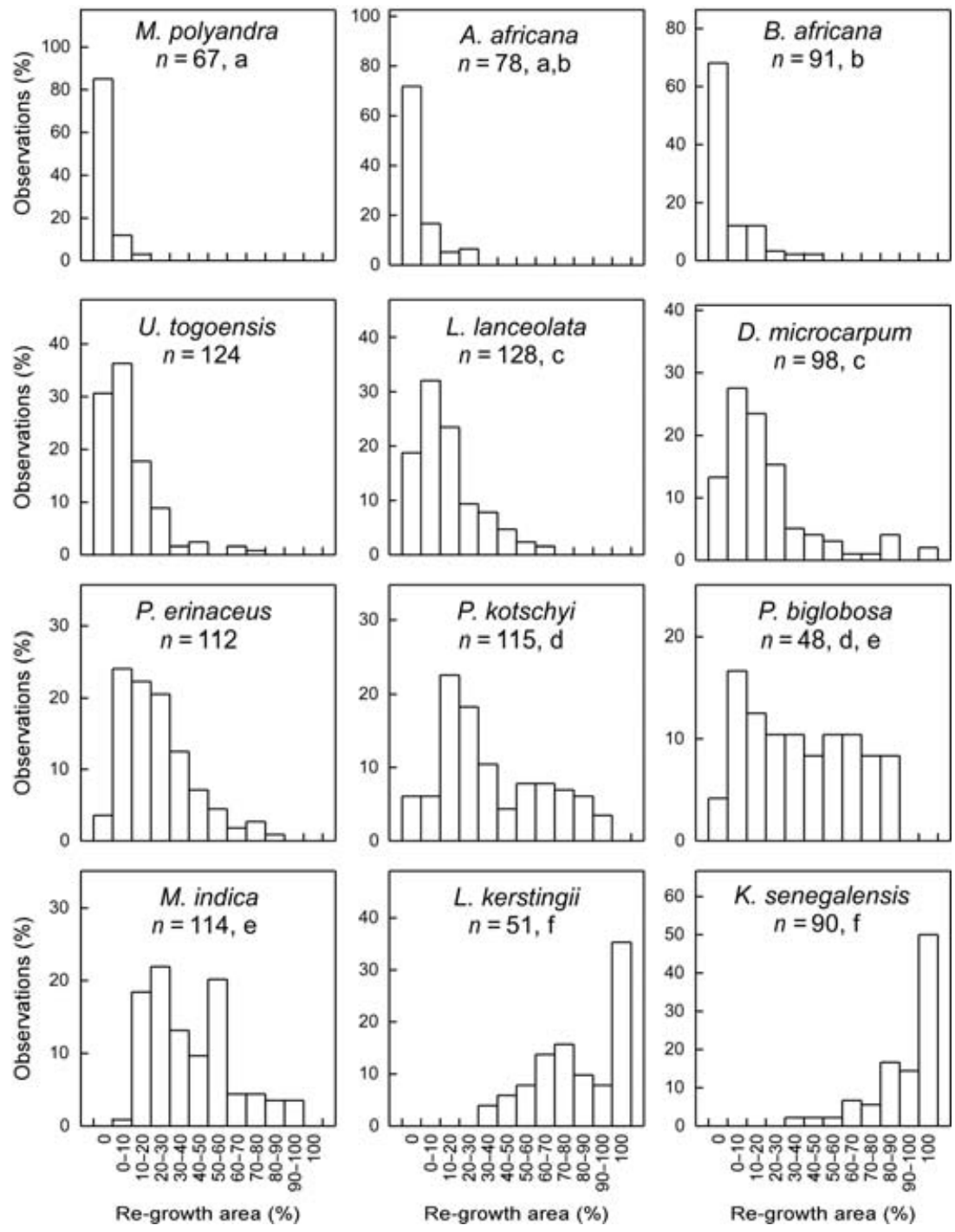

Fig. 3. Frequency histograms summarizing the edge growth of 12 medicinal tree species during 2 years following total bark harvesting. Identical small letters indicate species with no significant difference in edge growth at the $P \leq 0.05$ confidence level (proportional-odds logit model on score levels, see Table 2).

shoots (Fig. 5). M. polyandra presented a slightly greater ability to develop agony shoots than the other species, except for $A$. africana. For the other nine species, only $1-13 \cdot 6 \%$ of trees had developed agony shoots by the end of the observation period. No agony shoot was observed around the wound area of $L$. lanceolata. When a tree did develop agony shoots, there were usually only one or two, although $P$. biglobosa and U. togoensis produced a mean of 2.5 shoots per tree.

We noticed that $U$. togoensis produced roots around the wound area but we did not investigate this phenomenon further.

\section{Discussion}

The results of this study confirmed the hypothesis that tree response to bark harvesting is species-specific. However, over a period of 2 years after total bark harvesting, complete bark re-growth was rarely achieved, except for some $K$. senegalensis and L. kerstingii trees.

Despite some variability among the species tested, it was clear that a harvesting technique based on total bark removal did not favour sheet growth. These findings are consistent with

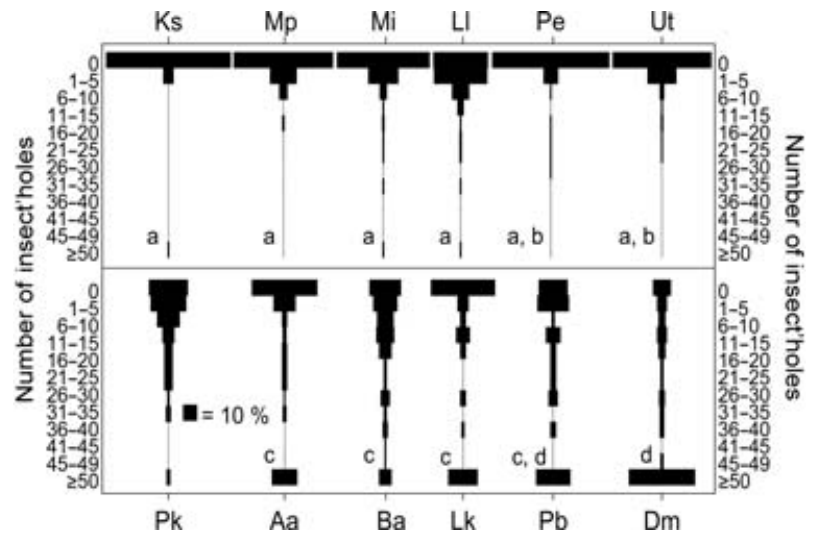

Fig. 4. Frequency histograms summarizing the susceptibility of the 12 medicinal tree species to insect attack during 2 years following total bark harvesting. Aa, Afzelia africana; Ba, Burkea africana; Dm, Detarium microcarpum; Ks, Khaya senegalensis; Lk, Lannea kerstingii; Ll, Lophira lanceolata; Mi, Mangifera indica; Mp, Maranthes polyandra; Pb, Parkia biglobosa; Pe, Pterocarpus erinaceus; Pk, Pseudocedrela kotschyi; Ut, Uapaca togoensis. Identical small letters indicate species with no significant difference in edge growth at the $P \leq 0 \cdot 05$ confidence level (GLM with species effect adjusted for different regeneration rates). 
the results of other studies of different tree species in southern Africa. According to W.J. Vermeulen \& C.J. Geldenhuys (unpublished data), only Ilex mitis and P. africana had good to poor sheet growth (11-60\% of re-growth); sheet growth was poor to absent for the four other species studied. Geldenhuys et al. (2007) found that, among 22 species harvested, five had good to very good sheet growth, five had poor sheet growth, and the 12 remaining species showed no sheet growth. Guedje (2002) observed that bark wounding in Garcinia lucida was not followed by any sheet growth. Similarly, Mariot, Mantovani $\&$ dos Reis (2007) studied bark harvesting from Drimys brasiliensis in southern Brazil and reported sheet growth to be almost non-existent.

Several experiments showed that the most important factor for successful recovery is the humidity of the exposed surface immediately after the wounding (Zimmermann \& Brown 1971; Zhengli et al. 1982; Neely 1988; McDougall \& Blanchette 1996; Stobbe et al. 2002; N'Koma Mwange, Hou \& Cui 2003; Juan et al. 2006). For this reason, those researchers covered the experimental wounds with plastic sheets to obtain significant re-growth. However, applying this technique in the wild is difficult. Consequently, we chose to harvest bark only partially, leaving a thin layer of bark and the cambium on the trunk. Our results demonstrate the protective effect of the remaining bark layer for promoting sheet growth. Compared to total bark removal, this technique increased the percentage of sheet growth significantly for each species studied (Fig. 2). However, a large variability in recovery was found among species: only four species, K. senegalensis, L. kerstingii, P. erinaceus, and $M$. indica, out of 12 showed a good recovery rate $(>40 \%)$. W.J. Vermeulen \& C.J. Geldenhuys (unpublished data) also studied the effect of leaving a thin layer of bark and the cambium in three species, and all of them showed a wound recovery rate of $50-80 \%$ of the wound surface, whereas none or poor recovery occurred when the bark and the cambium were removed completely.

Several studies have reported bark regeneration starting from the edge of the wound (e.g. W.J. Vermeulen \& C.J. Geldenhuys, unpublished data). Full recovery has been reported for Betula alleghaniensis (Shigo 1986), P. africana, Warburgia salutaris and Ficus natalensis (Cunningham \& Mbenkum 1993), G. lucida (Guedje 2002) and Ocotea bullata, I. mitis and P. africana (W.J. Vermeulen \& C.J. Geldenhuys, unpublished data). In this study, however, only $K$. senegalensis and L. kerstingii were able to close the wound completely over the 2-year follow-up period. Our results for $K$. senegalensis did not corroborate the findings reported by Gaoue \& Ticktin (2007), who noticed that, in most cases, less than half the wound area was recovered in this species. Our study found that $K$. senegalensis had an average recovery rate of $88.8 \%$ of the wound.

In the 12 species studied, we found a negative relationship between the number of insect holes and recovery rate. In this respect, our observations agree with those of Geldenhuys et al. (2007) who found that the level of infestation was greater in species that showed none or slow wound recovery. Our study showed susceptibility to insect attack depends on species, independent of regeneration rate. Amongst the 12 species in our study, D. microcarpum, P. biglobosa, L. kerstingii, $B$. africana and $A$. africana were susceptible to insect attack. One of the most severe effects of wood-boring insects is the failure of the tree at wound level due to large galleries dug deep inside the wood, which was observed for $17 \cdot 3 \%$ of the L. kerstingii individuals and, to a lesser extent, for P. biglobosa, but only $6.8 \%$ of individual stems of that species broke. The impact of insects on D. microcarpum, B. africana and $A$. africana was limited to the presence of numerous small holes on the wound surface. The insect holes also facilitated the entry of fungi, which further weakens the wood. Sealant can be applied to the affected area with the aim of limiting the impact of fungi (Botha et al. 2004).

Besides bark recovery, some of the harvested trees produced new roots and/or shoots (Guedje 2002). If the main trunk dies, the production of new shoots becomes an important survival mechanism. We observed this phenomenon for two B. africana trees: the main trunk died but agony shoots, developed beneath the wound, were alive and full of leaves. Burke (2006) observed the strong ability of B. africana to produce coppice shoots. Geldenhuys et al. (2007) suggested that the ability of a species to develop agony shoots around the wound after bark harvesting is related to the ability of that species to produce coppice shoots. Of the species in this study, only D. microcarpum has been studied for its ability to coppice (Sawadogo, Nygard \& Pallo 2002; Ky-Dembele et al. 2007) or to re-sprout (Rietkerk, Blijdorp \& Slingerland 1998; Sawadogo et al. 2002). In this study, only one out of 82 D. microcarpum trees developed agony shoots. M. polyandra showed the greatest ability to develop agony shoots, and it would be useful to test its coppicing ability. Luoga, Witkowski \& Balkwill (2004) studied the re-sprouting response of 44 species of East African miombo (African savanna) trees and reported the different factors influencing coppicing effectiveness, including the presence or absence of large herbivores and/or fire, season of cutting, site characteristics and speciesspecific characteristics. Coppices are a potential source of medicinal bark that could be optimized through active coppice management (Vermeulen 2006). Better knowledge of the complex coppicing response of individual tree species would help in the design of specific strategies for sustainable management of woodland containing medicinal tree species (Abbot \& Homewood 1999; Bond \& Rathogwa 2000; Geldenhuys 2004; Kaschula, Twine \& Scholes 2005; Neke, Owen-Smith \& Witkowski 2006; Ky-Dembele et al. 2007).

Our study has several implications for tree management. Harvesting bark requires species-specific techniques to make it sustainable. Sustainable harvesting must take into account the following species-specific factors: (i) the regeneration capacity (edge and/or sheet growth), which may allow for a second harvest; (ii) the susceptibility to insect attack, which may require additional protection measures; (iii) the capacity to develop agony shoots, which may enable the tree to produce coppice shoots. Depending on these factors, two broad management strategies exist: (i) management of tree species in existing natural forests; and (ii) development of alternative resources of medicinal plants outside the forest. Harvesting 


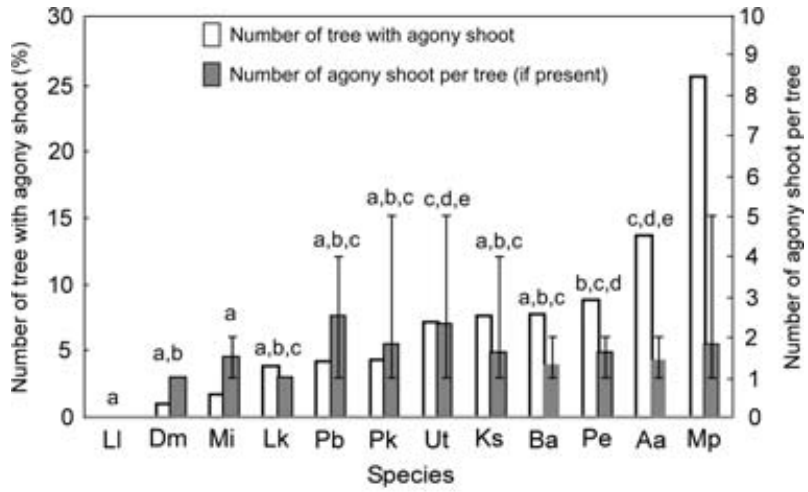

Fig. 5. Vegetative growth of the 12 medicinal tree species in response to bark harvesting. The percentage of trees with shoots and mean ( \pm range) of the number of agony shoots/tree with shoots are given. Identical small letters indicate species with no significant difference in edge growth at the $P \leq 0.05$ confidence level. See Fig. 4 for abbreviations.

trees in the wild may include strip harvesting and full-tree harvesting (harvesting of all utilizable bark from the trunk and branches of fallen trees). The latter is bark harvesting as a by-product of timber harvesting and coppice management (Vermeulen 2006). Harvesting trees from an alternative resource includes: establishing stands of the target species in open areas (clearing) and/or forest expansion at the forest edge (Geldenhuys \& Delvaux 2002), and harvesting leaves instead of bark. It has been suggested that leaves could be used instead of bark for medicinal purposes, and studies are underway in South Africa to compare the chemical composition of bark and leaves from the same tree (Zschocke et al. 2000a,b; Drewes et al. 2001). These methods of increasing bark availability would avoid over-exploitation of tree species in natural forests.

Following the methodology developed by Vermeulen (2006), our results provide the elements necessary to define a strategy that can help forest managers to select the most appropriate bark-harvesting system for different medicinal tree species. The first step involves categorizing species according to their ability to close the wound after bark has been removed, resistance to insect attack, and the ability to develop agony shoots (Table 2 and Fig. 6). The second step is to choose the appropriate harvest option depending on whether trees recover after bark harvesting: (i) strip harvesting for species with very good re-growth (level 4); or (ii) full-tree harvesting for species with none or little wound closure after bark harvesting (levels 1,2, and 3). The third step is to determine how to manage the full-tree harvesting technique according to species characteristics (e.g. through collaboration with a timber company, or via coppice management) and to determine the appropriate alternative solutions (stand establishment, harvesting leaves instead of bark, etc.).

Figure 7 gives an overview of the management techniques appropriate, on the basis of our findings, for the 12 species assessed in this study. Bark can be sustainably harvested from $K$. senegalensis and L. kerstingii. As the partial bark removal technique allowed a better sheet growth, it could be useful for

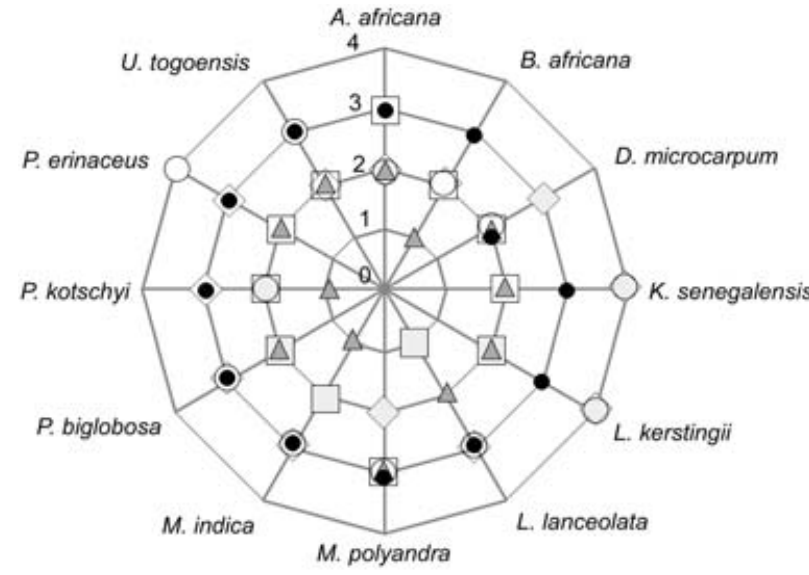

$\begin{array}{ll}\text { edge growth } & \Delta \text { sheet growhT } \\ \text { agony shoot } & \bigcirc \text { sheet growthP }\end{array}$

resistance against insects

Fig. 6. The response scores of the 12 medicinal tree species 2 years after bark harvesting. See Table 2 for further explanation of the variable responses and score levels.

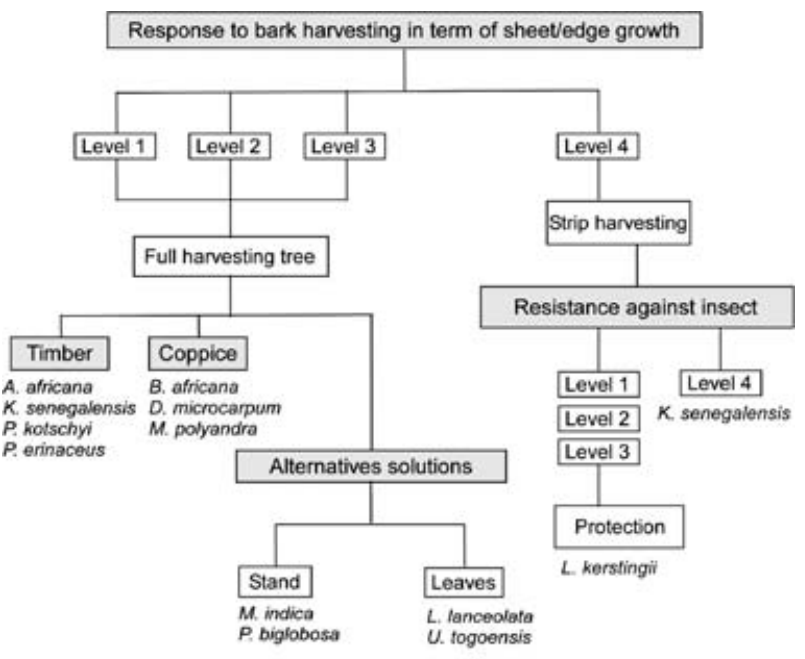

Fig. 7. The proposed management strategy for the 12 tree species in this study. The schema illustrates the successive steps needed to provide a decision strategy with the aim of selecting the most appropriate harvesting system for each species. See Table 2 for description of levels 1-4.

both species to cover the wound with plastic immediately after harvesting, but L. kerstingii must be protected from insect attack. The other 10 species did not exhibit a level of bark regeneration that would allow for a sustainable harvest. We therefore suggest full-tree harvesting for these species. This can be done in different ways, depending on the species. Harvesters looking for bark of A. africana, K. senegalensis, $P$. kotschyi and $P$. erinaceus may approach logging companies that are used to felling large numbers of these species. Bark can be removed without detriment to the wood quality when the tree is cut for timber. B. africana, D. microcarpum and M. polyandra may be cut at $1 \mathrm{~m}$ above-ground in order to favor coppice shoot development. M. indica and P. biglobosa should be planted on the forest edge, because they are light-tolerant 
species and they will be protected by local human populations who appreciate their fruits. For L. lanceolata, leaves could be harvested instead of bark. The chemical composition of the leaves and bark of L. lanceolata have been analysed (Pegnyemb et al. 1998) but further research is needed to determine the similarity. Thus, $L$. lanceolata could be managed as a kind of tea plantation, allowing faster, easier and more frequent harvesting. The results of this study suggest that $U$. togoensis could be used for coppice management. Very little information is available for $U$. togoensis, and it will be interesting to determine the concentration of the active component for medicinal use in the leaves and bark of this species.

\section{Acknowledgements}

This research was supported by VIIR project ZEIN 2003PR278. We are grateful to Bachirou Ignintonin and Roger Gantoli for their assistance with data collection in the field. We thank the anonymous referees whose comments have improved this paper.

\section{References}

Abbot, J.L.O. \& Homewood, K. (1999) A history of change: causes of miombo woodland decline in a protected area in Malawi. Journal of Applied Ecology, 36, 422-433.

Adjanohoun, E., Adjakidje, V., Ahyi, M.R.A., Ake Assi, L., Akoegninou, A., d'Almeida, J., Akpovo, F., Bouke, K., Chadare, M., Cusset, G., Dramane, K., Eyme, J., Gassita, J-N., Gbaguidi, N., Goudoté, E., Guinko, S., Hougnon, P., Issa, L.O., Keita, A., Kiniffo, H.V., Kone-Bamba, D., Musampa Nseyya, A., Saadou, M., Sodogandji, Th., de Souza, S., Tchabi, A., Zinsou Dossa, C. \& Zohoun, Th. (1989) Contribution aux études ethnobotaniques et floristiques en République Populaire du Bénin. ACCT, Paris.

Aloni, R. (1987) Differentiation of vascular tissues. Annual Review Plant Physiology, 38, 179-204.

Belcher, B., Ruiz-Pérez, M. \& Achdiawan, R. (2005) Global patterns and trends in the use and management of commercial NTFPs: implications for livelihoods and conservation. World Development, 33, 1435-1452.

Bockx, B. (2004) Ethnobotanische studie van geneeskrachtige planten in Manigri en Igbèrè, Benin. MSc Thesis, University of Ghent, Ghent, Belgium.

Bond, W. \& Rathogwa, N. (2000) Modelling savanna woodlands. Proceeding of 'Natural Forests and Woodlands Savanna' Symposium II, 5-9 September 1999, Pretoria, South Africa.

Botha, J., Witkowski, E.T.F. \& Shackleton, C.M. (2004) The impact of commercial harvesting on Warburgia salutaris ('pepper-bark tree') in Mpumalanga, South Africa. Biodiversity and Conservation, 13, 1675 1698.

Burke, A. (2006) Savanna trees in Namibia - factors controlling their distribution at the arid end of the spectrum. Flora, 201, 189-201.

Cunningham, A.B., (1991) Conservation of medicinal plants. Development of a Conservation Policy on Commercially Exploited Medicinal Plants: A Case Study from Southern Africa (eds O. Akerele, V. Heywood \& H. Synge), pp. 337-358. Cambridge University Press, Cambridge, UK.

Cunningham, A.B. \& Mbenkum, F.T. (1993) Sustainability of Harvesting Prunus Africana Bark in Cameroon. A Medicinal Plant in International Trade. Working paper 2. WWF/UNESCO/Kero People and Plant Initiative, Paris, France.

Davenport, T.R.B. \& Ndangalasi, H.J. (2002) An escalating trade in orchid tubers across Tanzania's Southern highlands-assessment, dynamics and conservation implication. Oryx, 37, 5-61.

Drewes, S.E., Crouch, N.R., Mashimbye, M.J., de Leeuw, B.M. \& Horn, M.M. (2001) A phytochemical basis for the potential use of Warburgia salutaris (pepper-bark tree) leaves in the place of bark. South African Journal of Science, 97, 383-386.

Endress, B.A., Gorchov, D.L. \& Noble, R.B. (2004) Non-timber forest product extraction: effect of harvest and browsing on an understory palm. Ecological Application, 14, 1139-1153.

Fasola, T.R. \& Egunyomi, A. (2005) Nigerian usage of bark in phytomedecine. Ethnobotany Research and Applications, 3, 73-77.

Gaoue, O.G. \& Ticktin, T. (2007) Patterns of harvesting foliage and bark from the multipurpose tree Khaya senegalensis in Benin: Variation across ecological regions and its impacts on population structure. Biological Conservation, 137, $424-436$.

Gaoue, O.G. \& Ticktin, T. (2008) Impact of bark and foliage harvest on Khaya senegalensis (Meliaceae) reproductive performance in Benin. Journal of Applied Ecology, 45, 3440.

Geldenhuys, C.J. (2004) Bark harvesting for traditional medicine: from illegal resource degradation to participatory management. Scandinavian Journal of Forest Research, 19, 103-115.

Geldenhuys, C.J. (2007) Restoring natural forests to make medicinal bark harvesting sustainable in South Africa. Restoring Natural Capital - Views from the South (eds J. Aronson \& S. Milton), pp. 170-178. SER/IP book series.

Geldenhuys, C.J. \& Delvaux C. (2002) Planting alternative resources of natural forest tree species for traditional medicine with seedlings collected from a Pinus patula stand, Nzimankulu forest. Report FW-04/02, FORESTWOOD cc, Pretoria, South Africa

Geldenhuys, C.J., Rau, D. \& Du Toit, L. (2002) Experimental Bark Harvesting from Selected Tree Species in the Southern Cape Forests - An Interim Report. CP Wild Project, Department of Forest Science, University of Stellenbosch, Stellenbosch, South Africa.

Geldenhuys, C.J., Syampungani, S., Meke, G.S. \& Vermeulen, W.J. (2007) Response of different species to bark harvesting for traditional medicine in Southern Africa. Multiple Use Management of Natural Forests and Woodlands: Policy Refinement and Scientific Progress (eds J.J. Bester, A.H.W. Seydack, T. Vorster, I.J. Van der Merwe \& S. Dzivhani), pp. 55-62. Department of Water Affairs and Forestry, Pretoria, South Africa.

Guedje, N.M. (2002) La gestion des populations d'arbres comme outil pour une exploitation durable des produits forestiers non-ligneux: l'exemple de Garcinia lucida (Sud-Cameroun). The Tropenbas-Cameroon Programme, Kribi, and Université Libre de Bruxelles, Brussels, 2002. Tropenbos-Cameroon Series 5, XVIII

Hall, P. \& Bawa, K. (1993) Methods to assess the impact of extraction of non-timber tropical forest products on plant populations. Economic Botany, 47, 234-247.

Hamilton, A.C. (2004). Medicinal plants, conservation and livelihoods. Biodiversity and Conservation, 13, 1477-1517.

Juan, D., Xie, H.L., Zhang, D.Q., He, X.O., Wang, M.J., Li, Y.Z., Cui, K.M. \& Lu, M.Z. (2006) Regeneration of the secondary vascular system in poplar as a novel system to investigate gene expression by a proteomic approach Proteomics, 6, 881-895.

Junikka, L. (1994) Survey of english macroscopic bark terminology. IAWA Journal, 15, 3-45.

Kaschula, S.A., Twine, W.E. \& Scholes, M.C. (2005) Coppice harvesting of fuelwood species on a South African common: utilizing scientific and indigenous knowledge in community based natural resource management. Human Ecology, 33, 387-418.

Ky-Dembele, C., Tigabu, M., Bayala, J., Ouedraogo, S.J. \& Oden, P.C. (2007) The relative importance of different regeneration mechanisms in a selectively cut savanna-woodland in Burkina Faso, West Africa. Forest Ecology and Management, 243, 28-38.

Light, M.E., Sparg, S.G., Stafford, G.I. \& van Staden, J. (2005) Riding the wave: South Africa's contribution to ethnopharmacological research over the las 25 years. Journal of Ethnopharmacology, 100, 127-130.

Luoga, E.J., Witkowski, E.T.D. \& Balkwill, K. (2004) Regeneration by coppicing (resprouting) of miombo (African savanna) trees in relation to land use. Forest Ecology and Management, 189, 23-35.

Mariot, A., Mantovani, A. \& dos Reis, M.S. (2007) Developing a basis for management of natural populations of Drimys brasiliensis in Brazil, used for its bark. Multiple Use Management of Natural Forests and Woodlands: Policy Refinement and Scientific Progress (eds J.J. Bester, A.H.W. Seydack, T. Vorster, I.J. Van der Merwe \& S. Dzivhani), pp. 76-81. Department of Water Affairs and Forestry, Pretoria, South Africa.

McDougall, D.N. \& Blanchette, R.A. (1996) Polyethylene plastic wrap for tree wounds: a promoter of wound closure on fresh wounds. Journal of Arboriculture, 22, 206-210.

N'koma Mwange, K., Hou, H.W. \& Cui, K.W. (2003) Relationship between endogenous indole-3-acetic acid and abscisic acid changes and bark recovery in Eucommia ulmoides Oliv. after girdling. Journal of Experimental Botany, 54, 1899-1907.

Neely, D. (1988) Wound closure rates on trees. Journal of Arboriculture, 14 250-254.

Neke, K.S., Owen-Smith, N. \& Witkowski, Ed, T.F. (2006) Comparative resprouting response of Savanna woody plant species following harvesting: the value of persistence. Forest Ecology and Management, 232, 114-123.

Pegnyemb, D.E., Messanga, B.B., Ghogomu, R., Sondengam, B.L. Martin, M.T. \& Bodo, B. (1998) A new benzoylglucoside and a new prenylated isoflavone from Lophira lanceolata. Journal of Natural Products, 61, 801-803.

(C) 2009 The Authors. Journal compilation (C 2009 British Ecological Society, Journal of Applied Ecology, 46, 703-712 
Peters, C.M. (1994) Sustainable Harvest of Non-Timber Plant Resources in Tropical Moist Forest: An Ecological Primer. Biodiversity Support Program - World Wildlife Fund, XIX. Washington, D.C.

R Development Core Team (2005) R: A language and environment for statistical computing, reference index version 2.2.1. R Foundation for statistical Computing, Vienna, Australia. ISBN 3-900051-07-0, URL: http://www.Rproject.org.

Rietkerk, M. Blijdorp, R. \& Slingerland, M. (1998) Cutting and resprouting of Detarium microcarpum and herbaceous forage availability in a semiarid environment in Burkina Faso. Agroforestry Systems, 41, 201-221.

Sawadogo, L., Nygard, R. \& Pallo, F. (2002) Effects of livestock and prescribed fire on coppice growth after selective cutting of Sudanian savannah in Burkina Faso. Annals of Forest Science, 59, 185-195.

Schippmann, U., Leaman, D.J. \& Cunningham, A.B. (2002) Impact of cultivation and gathering of medicinal plants on biodiversity: global trends and issues. Biodiversity and the Ecosystem Approach in Agriculture, Forestry and Fisheries. Food and Agriculture Organization, Rome.

Shackleton, S.E., Shackleton, C.M., Netshiluvhi, T.R., Geach, B.S., Balance, A. \& Fairbanks, D.H.K. (2002) Use patterns and value of savanna resources in three rural villages in South Africa. Economic Botany, 56, 130-146.

Shigo, A.L. (1986) A New Tree Biology - Facts, Photos, and Philosophies on Trees and Their Problems and Proper Care. Shigo and Trees, Associates, Durham, NH, USA

Shingu, G.K. (2005) Ownership and sustainability issues of botanical medicines. Ethnobotany Research \& Applications, 3, 17-23.

Srivastava, R. (2000) Studying the information needs of medicinal plant stakeholders in Europe. TRAFFIC Dispatches, 15, 5.

Stobbe, H., Schmitt, U., Eckstein, D. \& Dujesiefken, D. (2002) Developmental stages and fine structure of surface callus formed after debarking of living lime tree (Tilia sp.). Annals of Botany, 89, 773-782.
Ticktin, T. (2005) Applying a metapopulation framework to the management and conservation of a non-timber forest species. Forest Ecology and Management, 206, 249-261.

Trockenbrodt, M. (1990) Survey and discussion of the terminology used in bark anatomy. IAWA Bulletin, 11, 141-166.

Vermeulen, W.J. (2006) Sustainable bark harvesting for medicinal use: matching species to prescription. Paper Presented at the Workshop 'Trees for HealthForever - Implementing Sustainable Medicinal Bark use in Southern Africa' 1-3 November 2005, Willow Park, Johannesburg, South Africa.

Williams, V.L., Balkwill, K. \& Witkowski, E.T.F. (2000) Unraveling the commercial market for medicinal plants and plant parts on the Witwatersrand, South Africa. Economic Botany, 54, 310-327.

Witkowski, E.T.F. \& Lamont, B. (1994) Commercial picking of Banksia hookeriana in the wild reduces subsequent shoot, flower and seed production. Journal of Applied Ecology, 31, 508-520.

Zhengli, L., Keming, C., Chunsheng, Y. \& Xiaolin, C. (1982) Effect of plastic sheet wrapping upon girdled Eucommia ulmoides. Scientia Sinica, XXV, 368-375.

Zimmermann, M.H. \& Brown, C.L. (1971). Trees: Structure and Function. Springer Verlag, New York.

Zschocke, S., Drewes, S.E., Paulus, K., Bauer, R. \& van Staden, J. (2000a) Analytical and pharmacological investigation of Ocotea bullata (black stinkwood) bark and leaves. Journal of Ethnopharmacology, 71, 219-230.

Zschocke, S., Rabe, T., Taylor, J.L.S., Jäger, A.K. \& van Staden, J. (2000b) Plant part substitution - a way to conserve endangered medicinal plants? Journal of Ethnopharmacology, 71, 281-292.

Received 7 May 2008; accepted 12 February 2009

Handling Editor: Jos Barlow 